\title{
Behaviour change techniques and contraceptive use in low and middle income countries: a review
}

\author{
Mwelwa Phiri ${ }^{*}$, R. King ${ }^{2}$ and J. N. Newell ${ }^{2}$
}

\begin{abstract}
We aimed to identify effective behaviour change techniques to increase modern contraceptive use in low and middle income countries (LMICs). Literature was identified in Global Health, Web of Science, MEDLINE, PsycINFO and Popline, as well as peer reviewed journals. Articles were included if they were written in English, had an outcome evaluation of contraceptive use, modern contraceptive use, contraceptive initiation/uptake, contraceptive adherence or continuation of contraception, were a systematic review or randomised controlled trial, and were conducted in a low or middle income country. We assessed the behaviour change techniques used in each intervention and included a new category of male partner involvement. We identified six studies meeting the inclusion criteria. The most effective interventions were those that involve male partner involvement in the decision to initiate contraceptive use. The findings also suggest that providing access to contraceptives in the community promotes their use. The interventions that had positive effects on contraceptive use used a combination of behaviour change techniques. Performance techniques were not used in any of the interventions. The use of social support techniques, which are meant to improve wider social acceptability, did not appear except in two of the interventions. Our findings suggest that when information and contraceptives are provided, contraceptive use improves. Recommendations include reporting of behaviour change studies to include more details of the intervention and techniques employed. There is also a need for further research to understand which techniques are especially effective.
\end{abstract}

Keywords: Contraception, Community-based intervention, Behaviour change techniques, Low and middle income country

\section{Introduction}

More than $80 \%$ of unintended pregnancies occur in low and middle income countries (LMICs). With an unmet need for contraceptives of about $40 \%$, millions of women lack access to contraceptives [1, 2]. As a result, unsafe abortion is highly prevalent and contributes to high maternal mortality rates in LMICs [3]. More than $90 \%$ of abortion related mortality and morbidity can be avoided by using contraceptives $[1,3]$. In LMICs, contraceptive use also has a significant impact on child mortality, as well as having economic benefits $[3,4]$.

\footnotetext{
*Correspondence: muleba@gmail.com

Mwelwa Phiri and R. King are joint first authors.

'Public Health Practitioner, Lusaka Trust Hospital, 2191, Nsumbu road, P.O

.Box 35852, Lusaka, Zambia

Full list of author information is available at the end of the article
}

Community-based interventions to increase contraceptive use have been implemented in LMICs and have proved useful in reaching rural, hard to reach populations with limited access to static service delivery of contraceptives [3, 5]. However, the cost involved in increasing the reach of interventions is a hindrance. Cost, coupled with an uncertainty of what really works in changing reproductive behaviour $[3,5]$, is not conducive to scaling up interventions.

Most interventions, while having a component of behaviour change, are not clear about the behaviour change techniques (BCTs) employed [6,7]. BCTs are the essential building blocks of interventions [7]. It is important that health practitioners learn these techniques, as this allows community interventions to be replicated successfully. Where details of BCTs are not shared, this 
can lead to interventions being compromised [7]. It is therefore important to identify what techniques work to change reproductive behaviour in LMICs, as this will ensure programmes are designed effectively and that scarce resources are used appropriately and interventions are cost-effective [7].

This review identifies effective community-based interventions that increase modern contraceptive use in LMICs, somewhat akin to existing reviews $[5,8]$, however, our primary aim is to identify specific BCTs that have been proved to be effective in randomised controlled trials (RCTs), and provide recommendations on which particular techniques should be included in the design of future interventions.

For the purposes of this review, contraception refers to use of modern contraceptives including:

- long acting methods such as male and female sterilisation, IUDs, implants, and injectables; and

- Short acting methods such as pills, male and female condoms and other supply methods, such as spermicides.

However, we acknowledge that contraception does not merely encompass modern contraceptives [9].

\section{Methods}

\section{Search strategy}

The following databases were used to identify relevant articles: Global Health, Web of Science, MEDLINE, PsycINFO and Popline. Peer reviewed journals searched were Social Science and Medicine, Contraception, Studies in Family Planning, Reproductive Health Matters and Health Education Research.
Key search terms were "low and middle income countries"; "developing countries"; "contraception"; "family planning"; "randomised controlled trials"; and "systematic reviews". Subject headings of the key terms and text word terms were used for a comprehensive search. Reference lists of identified articles were also searched. The search was limited by the type of study design (Systematic reviews and randomised controlled trials) and the above search terms. This restriction to RCTs and Systematic reviews is because they are the two study designs which will answer our research question particularly on the effectiveness of interventions and robustness of the interventions. The studies were assessed on relevance to the topic. This is because of the varied meanings of community-based interventions. This broad search strategy was developed with Dr Rebecca King and Judy Wright (Information specialist). Summary journal searches are in Table 1.

\section{Screening and papers selection criteria}

Two researchers screened titles and abstracts independently and discussed any differences and areas for further assessment. Full text assessments were done by the primary author and the shortlisted articles were independently reviewed by the second author for inclusion, differences were resolved by discussion and consultation with the third author.

Any differences in assessment were resolved by a third researcher.

Our inclusion criteria were:

- English language papers;

- Studies with an outcome evaluation of contraceptive use, modern contraceptive use, contraceptive

Table 1 Summary of journal search strategy

\begin{tabular}{|c|c|c|}
\hline Journal & No. of hits & Search terms \\
\hline Social science and medicine & 744 & $\begin{array}{l}\text { (family planning OR contraceptive use AND developing } \\
\text { countries OR low and middle income countries OR low } \\
\text { income countries OR third world countries) }\end{array}$ \\
\hline Contraception & 664 & $\begin{array}{l}\text { Keywords: family planning OR contraceptive use in } \\
\text { developing countries }\end{array}$ \\
\hline \multirow[t]{2}{*}{ Studies in family planning } & 525 & $\begin{array}{l}\text { family planning OR contracept* AND developing countries } \\
\text { in Studies in Family Planning }\end{array}$ \\
\hline & 411 & $\begin{array}{l}\text { ((family planning OR contracept* AND developing countries } \\
\text { OR low AND middle income countries OR low income } \\
\text { countries OR third world countries AND systematic review* } \\
\text { OR randomized controlled trial*) AND jid:(j100383)) AND } \\
\text { (systematic reviews OR RCTs OR interventions) }\end{array}$ \\
\hline Reproductive health matters & 882 & Used keywords of family planning and contraceptive use \\
\hline Health education research & 267 & $\begin{array}{l}\text { Searching journal content for family planning, contracept* } \\
\text { (any words) in title or abstract and family planning, } \\
\text { contraception, developing countries, reviews, randomized } \\
\text { controlled trials (any words) in full text. }\end{array}$ \\
\hline
\end{tabular}


initiation/uptake, contraceptive adherence or continuation of contraception;

- Systematic reviews and RCTs in LMICs (World Bank classification); and

- Studies meeting methodological rigour of behaviour change intervention assessment based on four criteria by Michie and Abraham [10]. These criteria are: 1) random allocation or matched control group; 2) pre and post intervention data reporting; 3) reporting intention to treat analysis; and 4) reporting all outcomes indicated by aims and objectives of the study [10].

\section{Assessing behaviour change techniques}

Authors were contacted for additional information about the BCTs they used, or for further descriptions of the methodologies they used. To identify BCTs, we used the method identified by Briscoe and Aboud [6] who classified 26 BCTs initially identified by Abraham and Michie [7] into six broad categories which included new techniques not included in the Abraham and Michie [7] list.
These categories were: 1) information; 2) performance; 3) problem solving; 4) social support; 5) materials; and 6) media. We also identified a new category: 7) male partner involvement.

\section{Results}

\section{Search flow}

The reviewers identified 3150 publications in the data base search and 3493 publications in the journal search. After screening titles and abstracts and removing duplicates, 90 studies were selected for further assessment. After further screening, six studies were included in the review. Details are provided in Fig. 1.

\section{Study details}

The studies reviewed were published in 5 journals. These were conducted in Syria, Ethiopia, Zambia, Malawi, Nepal and Uganda. All studies were RCTs. Table 2 gives a brief description of the studies included in the review.

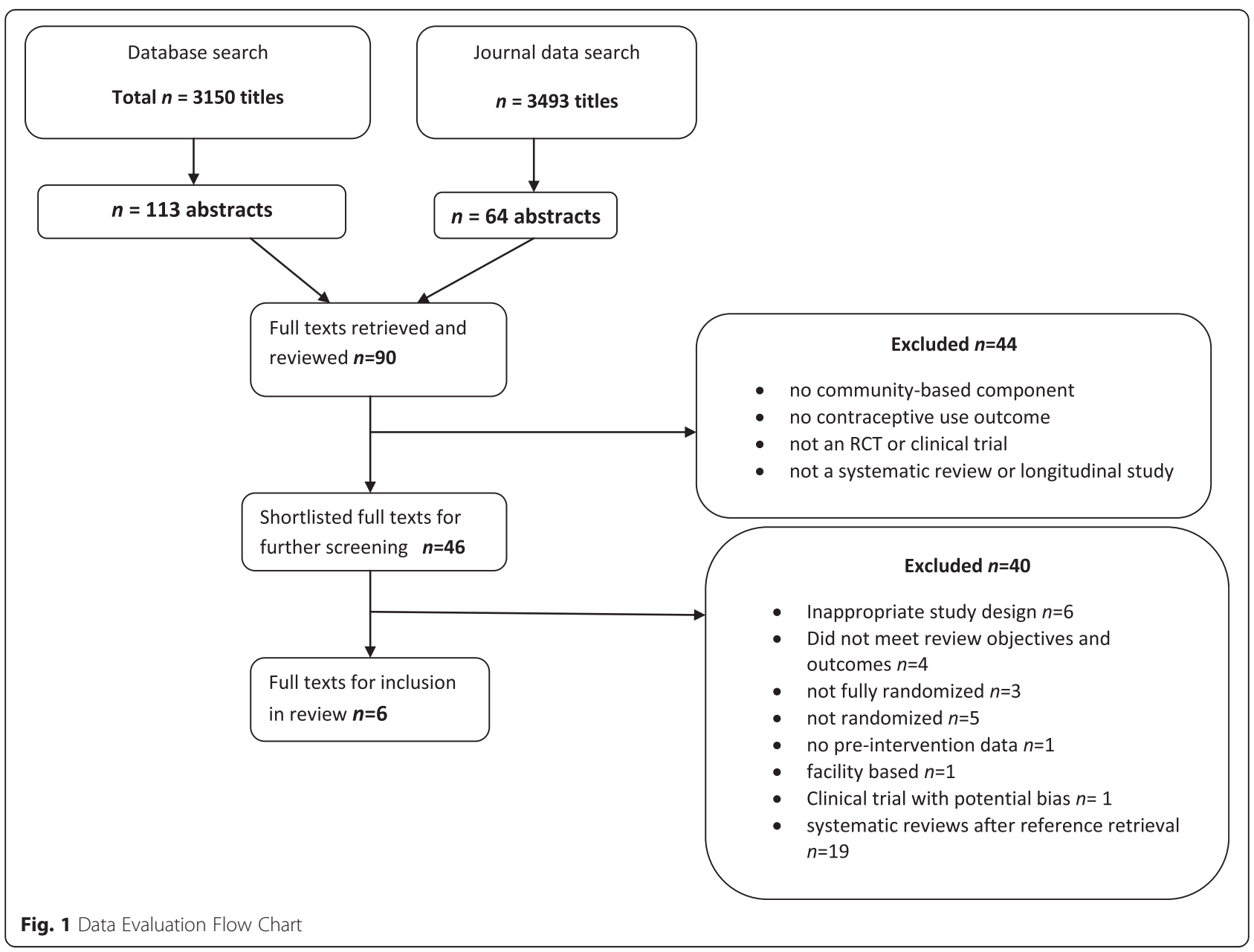


Table 2 Summary of interventions

\begin{tabular}{|c|c|c|c|c|c|c|c|c|}
\hline Authors & $\begin{array}{l}\text { Country } \\
\text { conducted } \\
\text { in }\end{array}$ & $\begin{array}{l}\text { Delivered by and } \\
\text { where }\end{array}$ & Recipient of intervention & $\begin{array}{l}\text { Specific contraceptives } \\
\text { included }\end{array}$ & Duration and intensity & $\begin{array}{l}\text { Design of } \\
\text { intervention }\end{array}$ & $\begin{array}{l}\text { Post test and } \\
\text { follow-up }\end{array}$ & Sample size \\
\hline Bashour et al. 2008 & Syria & $\begin{array}{l}\text { Registered midwives: } \\
\text { Home Visit (HV) }\end{array}$ & Post-partum women & $\begin{array}{l}\text { Pills, IUD, condoms, natural } \\
\text { methods. }\end{array}$ & $\begin{array}{l}5 \text { home visits on } \\
\text { day } 1,3,7 \text { and } 30 \text {. }\end{array}$ & $\mathrm{RCT}$ & 4 months postpartum & 876 women \\
\hline Terefe and Larson 1993 & Ethiopia & $\begin{array}{l}\text { Trained TBA and } \\
\text { female } H A(H V)\end{array}$ & $\begin{array}{l}\text { Married women living } \\
\text { with husbands }\end{array}$ & $\begin{array}{l}\text { Pills, copper IUD and } \\
\text { condoms }\end{array}$ & 2 home visits & $\mathrm{RCT}$ & $\begin{array}{l}2 \text { months and } \\
12 \text { months post } \\
\text { intervention }\end{array}$ & 527 couples \\
\hline Stephenson et al. 2011 & Zambia & Video and counsellor & $\begin{array}{l}\text { HIV-serodiscordant and } \\
\text { concordant couple }\end{array}$ & $\begin{array}{l}\text { Condoms, pills, injectables, } \\
\text { Norplant, IUD and tubal } \\
\text { litigation }\end{array}$ & $\begin{array}{l}30 \text { min video and } \\
\text { Q\&A with counsellor }\end{array}$ & $\mathrm{RCT}$ & immediately & $\begin{array}{l}1178 \text { couples } \\
\text { (condoms and } \\
\text { nonusers) }\end{array}$ \\
\hline Shattuck et al. 2011 & Malawi & Male motivator(HV) & Male partners & $\begin{array}{l}\text { Condoms, injectables, pills, } \\
\text { IUD, diaphragms and male } \\
\text { sterilization }\end{array}$ & $\begin{array}{l}5 \text { visits over } \\
6 \text { months }\end{array}$ & $\mathrm{RCT}$ & $\begin{array}{l}7 \text { months. } 1 \text { month } \\
\text { after last visit. }\end{array}$ & 400 men \\
\hline Bolam et al. 1998 & Nepal & $\begin{array}{l}\text { Female health } \\
\text { educators, midwives } \\
\text { \& } \mathrm{CHW}(\mathrm{HV})\end{array}$ & Post-partum women & Not detailed. & $\begin{array}{l}1 \text { post-partum, } 1 \\
\text { home visit }\end{array}$ & $\mathrm{RCT}$ & 6 months & 540 women \\
\hline Lutalo et al. 2010 & Uganda & $\begin{array}{l}\text { SDPs, COBRAs, opinion } \\
\text { leaders, users, TBAs(HV) }\end{array}$ & $\begin{array}{l}\text { Sexually active non } \\
\text { pregnant women, } \\
\text { sexuallyactive men }\end{array}$ & $\begin{array}{l}\text { Pill, injectables and } \\
\text { condoms }\end{array}$ & $\begin{array}{l}3 \text { years continuous } \\
\text { activity }\end{array}$ & $\mathrm{RCT}$ & 3 years post intervention & 10,294 couples \\
\hline
\end{tabular}




\section{Key findings}

The most effective interventions appear to be those that involve male partner involvement in the decision to initiate contraceptive use [11-14]. This is shown in Table 3. However, two of these studies $[11,13]$ consisted of selfreporting of contraceptive use either in the presence of the male partners or by the male partners. As the methods included in the studies were female user dependent (pills and injectables), this could affect the validity of the results, as male partners may not have been present when their female partners used the contraceptive.

The studies conducted among post-partum women suggest that interventions targeting women only are not as effective as those that target couples. In the Bashour et al. [15] study using educative post-natal home visits by midwives in Syria, there was no significant difference in contraceptive uptake between research arms for contraceptive use (42\%, $37 \%$ and $40.5 \%$ ). This low evidence of effectiveness is congruent with a Cochrane review on post-natal education, which found low evidence of effectiveness and suggested further research [8].

The findings also suggest that providing immediate access to contraceptives in the community promotes their use. Trials of interventions that included onsite provision, as opposed to referral to health facilities, [12-14] showed better uptake than the other studies that did not provide the contraceptives. However, the uptake in all the studies were fairly modest. While the study by Stephenson et al on serodiscordant couples appeared to be effective, it was conducted among HIV positive serodiscordant and concordant couples. This could affect how the intervention is used with other target groups, as the HIV status of the couples could be a major determinant in whether they use family planning [14].

\section{Behaviour change techniques}

Table 3 identifies which interventions utilised which techniques and the effectivness of the interventions. We identified BCTs from four of the six Briscoe and Aboud [6] categories. We also identified male partner involvement as an additional category that had not been explicitly identified. The most successful interventions used multiple BCTs as shown in Table 3.

\section{Technique one: information techniques}

Information techniques were used in all the interventions and included providing information on the available methods, importance and advantages of methods, ill effects of large families, misconceptions about methods and explanations of methods, including side effects and efficacy [11-16]. This information was mostly provided orally and face-to-face. Two interventions used a video to provide information with one adding a description of the methods on the patient consent form. One intervention also used drama, role playing and music to provide information. Peers, authority figures such as healthcare professionals, and community health workers (CHWs) provided this information.

\section{Technique two: performance techniques}

None of the interventions included modelling behaviour, observation, demonstrations or practice by the participants. One intervention included providing instructions for correct condom use [11] but did not explicitly perform or demonstrate correct condom use.

\section{Technique three: problem-solving techniques}

The technique of 'discussing any problems and help' during a home visit was used and described in detail in one of the interventions [15]. However, this was not explicitly used for contraceptive uptake. Problem-solving techniques were mentioned in one other intervention but were not adequately described.

\section{Technique four: social support techniques}

Social support techniques included using male role models (or peers) to normalise contraceptive use, training opinion leaders to disseminate family planning information, involving community residents to choose volunteer role models from within the community, and using authority figures such as health practitioners. Social support techniques were used in two interventions.

\section{Technique five: providing materials}

Providing materials included providing contraceptive pills and condoms on site. Injectables were provided only in the event of a medical practitioner volunteer being present in one of the interventions. Social marketing was used in one of the interventions for providing the pill, injectables and condoms. Material provision was used by three of the six interventions. If contraceptives could not be provided, participants were given information on where to access them.

\section{Technique six: media techniques}

Media techniques consisted of using short videos to provide information, illustrating scenarios using drama and role plays, music and print media such as flip charts, leaflets, booklets and posters. Print media was provided as a supplement to the oral information in two of the interventions. None of the interventions used mass media. One intervention also contained a brief description of the methods on the patient consent form. Media techniques were used by three of the six interventions. 
Table 3 Summary of behaviour change techniques using Briscoe and Aboud's [7] categories

\begin{tabular}{|c|c|c|c|c|c|c|c|c|c|c|}
\hline \multirow[t]{2}{*}{ Study } & \multirow[t]{2}{*}{ Outcomes } & \multirow[t]{2}{*}{ Effectiveness } & \multirow{2}{*}{$\begin{array}{l}\text { Observed } \\
\text { behaviour }\end{array}$} & \multicolumn{7}{|c|}{ Techniques of behaviour change } \\
\hline & & & & Information & Performance & $\begin{array}{l}\text { Problem } \\
\text { solving }\end{array}$ & Social support & Materials & Media & $\begin{array}{l}\text { Male partner } \\
\text { involvement/ } \\
\text { participation }\end{array}$ \\
\hline $\begin{array}{l}\text { Bashour et al. } \\
2008\end{array}$ & Contraceptive uptake & $\begin{array}{l}\text { Intervention- } \\
37 \% ; 40 \% \text { and } \\
42 \% \text { across } \\
\text { arms }\end{array}$ & $\begin{array}{l}\text { No significant } \\
\text { difference between } \\
\text { arms. Self-reported }\end{array}$ & Health education & - & $\begin{array}{l}\text { Discussion } \\
\text { of problems }\end{array}$ & - & - & - & - \\
\hline $\begin{array}{l}\text { Terefe and } \\
\text { Larson } 1993\end{array}$ & Contraceptive use & $\begin{array}{l}\text { Intervention } \\
47 \% \text {,control } \\
33 \%\end{array}$ & $\begin{array}{l}\text { Contraceptive use } \\
\text { and continuation }\end{array}$ & Health education & - & - & - & $\begin{array}{l}\text { If requested, } \\
\text { pills and } \\
\text { condoms }\end{array}$ & - & $\begin{array}{l}\text { Couple } \\
\text { administered } \\
\text { information }\end{array}$ \\
\hline $\begin{array}{l}\text { Stephenson } \\
\text { et al. } 2011\end{array}$ & $\begin{array}{l}\text { Modern contraceptive } \\
\text { uptake and switching }\end{array}$ & $\begin{array}{l}\text { baseline use } \\
21.5 \% \text {, after } \\
\text { intervention- } \\
93.6 \%\end{array}$ & $\begin{array}{l}\text { Uptake of } \\
\text { contraceptives, } \\
\text { switching and } \\
\text { addition if using } \\
\text { condoms only }\end{array}$ & Information & - & - & - & $\begin{array}{l}\text { If requested, } \\
\text { pills, } \\
\text { injectables, } \\
\text { Norplant }\end{array}$ & $\begin{array}{l}\text { Video, Print } \\
\text { media }\end{array}$ & $\begin{array}{l}\text { Couple } \\
\text { administered } \\
\text { intervention }\end{array}$ \\
\hline $\begin{array}{l}\text { Male motivator } \\
\text { project, Shattuck } \\
\text { et al. } 2011\end{array}$ & $\begin{array}{l}\text { Family planning } \\
\text { uptake }\end{array}$ & $\begin{array}{l}\text { intervention- } \\
78 \% \text {, control- } \\
59 \%\end{array}$ & Self-reported & $\begin{array}{l}\text { Information from } \\
\text { peers }\end{array}$ & - & - & Peers & - & - & $\begin{array}{l}\text { Male partner } \\
\text { only } \\
\text { administered } \\
\text { intervention }\end{array}$ \\
\hline $\begin{array}{l}\text { Bolam et al. } \\
1998 \text { postnatal } \\
\text { health education }\end{array}$ & $\begin{array}{l}\text { Uptake of FP services } \\
\text { or contraceptive use, } \\
\text { Two different outcomes, } \\
\text { self-reported }\end{array}$ & $\begin{array}{l}\text { intervention- } \\
20 \% \text {, control- } \\
14 \%\end{array}$ & Self-reported & $\begin{array}{l}\text { Information on } \\
\text { importance of FP, } \\
\text { location of nearest } \\
\text { clinic, choice of } \\
\text { methods. }\end{array}$ & - & - & - & - & $\begin{array}{l}\text { Cloth flip charts } \\
\text { developed by } \\
\text { local artist. }\end{array}$ & - \\
\hline $\begin{array}{l}\text { Lutalo et al. } \\
2010\end{array}$ & $\begin{array}{l}\text { Contraceptive use } \\
\text { prevalence }\end{array}$ & $\begin{array}{l}\text { intervention- } \\
23 \% \text {, control- } \\
20 \%\end{array}$ & $\begin{array}{l}\text { Contraceptive use } \\
\text { and uptake }\end{array}$ & $\begin{array}{l}\text { Information at } \\
\text { meetings. }\end{array}$ & - & - & $\begin{array}{l}\text { Opinion leaders } \\
\text { and certified } \\
\text { users of FP, } \\
\text { volunteers chosen } \\
\text { by communities }\end{array}$ & $\begin{array}{l}\text { Provision of } \\
\text { pills, } \\
\text { condoms }\end{array}$ & $\begin{array}{l}\text { Videos, role play, } \\
\text { drama, IEC } \\
\text { material- leaflets, } \\
\text { booklets and } \\
\text { posters }\end{array}$ & - \\
\hline
\end{tabular}




\section{New technique: male partner involvement}

Involving male partners is a technique that was used in three of the interventions. In two of the interventions this was by delivering the intervention in the presence of either the husband or partner with the female partner. Methods used included providing information and contraceptives. One intervention used information techniques that specifically targeted the male partners only.

\section{Discussion}

The results described above of the included studies suggest several things, firstly, that the most effective interventions appear to be those that involve male partner involvement in the decision to initiate contraceptive use and utilise a combination of behaviour change techniques as opposed to use of only one technique [11-14]. This is also why the authors identified this as a new and separate category. However, two of the studies [11, 13] consisted of self reporting of contraceptive use either in the presence of the male partners or by the male partners, and as the methods included in the studies were female user dependent (Pills and injectables), this could be a possible source of bias and could potentially affect the validity of the results.

Secondly, the results also suggest that interventions that provide access to contraceptives on site at the time of implementation promote use. This is alluded to and is suggested as a prompt to use in the studies in Zambia, Ethiopia and Uganda as opposed to referral to health facilities, this is supported as the results in these countries are better than for the other reported studies [12-14]. However, the results in all the studies were fairly modest and did see an increase in use across all arms. It should be noted that while the study in Zambia appeared to be effective, it was conducted among HIV positive serodiscordant and concordant couples, this could affect the applicability of the intervention in other target groups and the HIV status of the couples could be a major determinant in the use of contraceptives [14].

It should also be noted that all the interventions consisted of married or cohabiting couples, which would also impact the applicability of the interventions to groups such as adolescents or unmarried women and other underserved populations.

Thirdly, the results of studies conducted among post partum women only suggest that interventions that target women only are not as effective as those that target couples. In the study conducted in Syria, there was no difference between arms in terms of contraceptive use and there was only a small albeit significant effect in the study conducted in Nepal $[15,16]$. These results however should be taken with caution considering these two trials used only one or two BCTs. This low evidence of effectiveness is however, congruent with a
Cochrane review on post natal education which found the evidence of effectiveness as low and suggested further research [8].

These results also suggest that interventions that include home visits do have more of an impact and are a component of all but one of the interventions.

\section{Limitations of this review}

One of the limitations of this review was that it was restricted to English language only papers; this could have resulted in missed studies published in languages other than English. Another limitation is it was restricted to RCTs only and so could have missed studies that could have been effective and had used other BCTs that were not identified in our review. Also, based on our definition of $\mathrm{CBI}$, this could have limited our results. However, the review used general search terms for contraception use and authors were contacted for additional information particularly with regard to behaviour change techniques or for any further description of the methodology and the techniques. Additionally, most of the interventions were not reported in detail and therefore it was difficult to extract information on the BCTs. Finally, as all the interventions targeted married or cohabiting couples, the BCTs may not be applicable to underserved populations such as adolescents and unmarried women.

\section{Recommendations}

The findings described and discussed above provide some insight into what could work to increase family planning use in LMIC. Despite having reporting positive results, the findings would require further research and evaluation to be able to generalise the findings. Further projects and research could include male involvement as it has shown to be promising, however, the context in which the intervention is taking place should be considered particularly with regard to gender and power in that particular context. The design of the further research recommended should be stronger to better illustrate effectiveness.

We would also recommend the inclusion of more details in reporting, particularly with regard to BCTs to allow for reliability of what works and also for disaggregation of the effect of individual BCTs. The costs involved may be limiting in this instance but the detailed reporting would be very useful for future implementation and replication.

We would also recommend the use of multiple BCTs to increase contraceptive use, with at least provision of information about the methods and the provision of contraceptives on site as opposed to referrals to static health facilities as the studies which provided on site materials showed greater strength. BCT categories that 
support the first two categories and could be included are the use of media, social support and role models.

Finally, as it is difficult to disaggregate the effectiveness of individual techniques, we recommend further research to understand which techniques are especially effective. In particular, we recommend further investigation of performance techniques, problem-solving techniques and social support techniques. However, it may be the case that only a combination of BCTs will be effective.

\section{Abbreviations}

BCT: Behaviour change technique; CHW: Community health worker; LMIC: Low and middle income country; RCT: Randomised controlled trial; HV: Home visit.

\section{Competing interests}

The authors declare that they have no competing interests.

\section{Authors' contributions}

MP screened titles and abstracts, sampled the results, conducted the full text assessments, and made substantial contributions to drafting the manuscript. RK conceived the study, screened titles and abstracts, sampled the results, reviewed shortlisted full text papers, and made substantial contributions to drafting the manuscript. JN contributed to the design of the study, resolved any differences in paper assessment and made substantial contributions to drafting the manuscript. All authors read and approved the final manuscript.

\section{Acknowledgements}

We thank Judy Wright for support in designing the search strategy. We thank Nilam Ashra-MacGrath for advice on drafting the manuscript and substantial contributions to editing.

\section{Author details}

'Public Health Practitioner, Lusaka Trust Hospital, 2191, Nsumbu road, P.O Box 35852, Lusaka, Zambia. ${ }^{2}$ Nuffield Centre for International Health and Development, Leeds Institute of Health Sciences, Clarendon Road, Leeds LS2 9LJ, UK.

Received: 18 March 2015 Accepted: 25 October 2015

Published online: 30 October 2015

\section{References}

1. Tripney J, Kwan I, Bird KS. Postabortion family planning counseling and services for women in low-income countries: a systematic review. Contraception. 2013;87(1):17-25.

2. Malarcher S, Merrick O, Lebetkin E, Shah I, Speiler J, Stanback J. Provision of DMPA by community health workers: what the evidence shows. Contraception. 2011;83(6):495-503.

3. Cleland J, Bernstein S, Ezeh A, Faundes A, Glasier A, Innis J. Family planning: the unfinished agenda. Lancet. 2006;368(9549):1810-27.

4. Cleland J, Conde-Agudelo A, Peterson H, Ross J, Tsui A. Contraception and health. Lancet. 2012;380(9837):149-56.

5. Mwaikambo L, Speizer IS, Shurmann A, Morgan G, Fikree F. What works in family planning interventions: a systematic review. Stud Fam Plann. 2011:42(2):67-82.

6. Briscoe C, Aboud F. Behaviour change communication targeting four health behaviours in developing countries: a review of change techniques. Soc Sci Med. 2012;75(4):612-21.

7. Abraham C, Michie S. A taxonomy of behavior change techniques used in interventions. Health Psychol. 2008;27(3):379-87.

8. Lopez LM, Hiller JE, Grimes DA, Chen M. Education for contraceptive use by women after childbirth. Cochrane Database Syst Rev. 2012;8:pCD001863.

9. Singh S, Darroch JE. Adding it up: Costs and benefits of contraceptive services.New York: Guttmacher Institute and UNFPA; 2012. http://www. guttmacher.org/pubs/AlU-2012-estimates.pdf.

10. Michie S, Abraham C. Interventions to change health behaviours: evidencebased or evidence-inspired? Psychol Health. 2004;19(1):29-49.
11. Shattuck D, Kerner B, Gilles K, Hartmann M, Ng;ombe T, Guest G. Encouraging contraceptive uptake by motivating men to communicate about family planning: the Malawi Male Motivator project. Am J Public Health. 2011:101(6):1089-95.

12. Terefe A, Larson C. Modern contraception use in Ethiopia: does involving husbands make a difference? Am J Public Health. 1993:83(11):1567-71.

13. Lutalo T, Kigozi G, Kimera E, Serwadda D, Wawer MJ, Zabin LS, et al. A randomized community trial of enhanced family planning outreach in Rakai, Uganda. Stud Fam Plann. 2010;41(1):55-60.

14. Stephenson R, Vwalika B, Greenberg L, Ahmed Y, Vwalika C, Chomba E, et al. A randomized controlled trial to promote long-term contraceptive use among HIV-serodiscordant and concordant positive couples in Zambia. J Womens Health. 2011:20(4):567-74.

15. Bashour H, Kharouf MH, AbdulSalam AA, Asmar KE, Tabbaa MA, Cheikha SA. Effect of postnatal home visits on maternal/infant outcomes in Syria: a randomized controlled trial. Public Health Nurs. 2008;25(2):115-25.

16. Bolam A, Manandher DS, Shrestha P, Ellis M, Costello AML. The effects of postnatal health education for mothers on infant care and family planning practices in Nepal: a randomised controlled trial. BMJ. 1998:316(7134):805-11.

\section{Submit your next manuscript to BioMed Central and take full advantage of:}

- Convenient online submission

- Thorough peer review

- No space constraints or color figure charges

- Immediate publication on acceptance

- Inclusion in PubMed, CAS, Scopus and Google Scholar

- Research which is freely available for redistribution 